\title{
Characterization of electroless nickel as a seed layer for silicon solar cell metallization
}

\author{
MEHUL C RAVAL ${ }^{1,2, *}$ and CHETAN S SOLANKI ${ }^{1,2}$ \\ ${ }^{1}$ National Center for Photovoltaic Research and Education (NCPRE), Indian Institute of Technology-Bombay, Powai, \\ Mumbai 400 076, India \\ ${ }^{2}$ Department of Energy Science and Engineering, Indian Institute of Technology-Bombay, Powai, Mumbai 400076 , India
}

MS received 22 April 2014

\begin{abstract}
Electroless nickel plating is a suitable method for seed layer deposition in Ni-Cu-based solar cell metallization. Nickel silicide formation and hence contact resistivity of the interface is largely influenced by the plating process and annealing conditions. In the present work, a thin seed layer is deposited from neutral pH and alkaline electroless nickel baths which are annealed in the range of $400-420^{\circ} \mathrm{C}$ for silicide morphology and contact resistivity studies. A minimum contact resistivity of $7 \mathrm{~m} \Omega \mathrm{cm}^{2}$ is obtained for seed layer deposited from alkaline bath. Silicide formation for Pd-activated samples leads to uniform surface morphology as compared with unactivated samples due to non-homogeneous migration of nickel atoms at the interface. Formation of nickel phosphides during annealing and the presence of $\mathrm{SiO}_{2}$ at $\mathrm{Ni}-\mathrm{Si}$ interface creates isolated $\mathrm{Ni}_{2} \mathrm{Si}-\mathrm{Si}$ interface with limited supply of silicon. Such an interface leads to the formation of high resistivity metal-rich $\mathrm{Ni}_{3} \mathrm{Si}$ silicide phase which limits the reduction in contact resistivity.
\end{abstract}

Keywords. Ni-Cu metallization; electroless nickel; contact resistivity; nickel silicide; nickel phosphides.

\section{Introduction}

Silver-based front-side metallization is an established technology for silicon solar cells. However, the presence of glassfrit and voids in silver paste reduces the effective density and conductivity of silver grid lines. ${ }^{1}$ In addition, contribution of metallization to cell processing cost is around $40 \%$ due to the expensive silver paste. ${ }^{2}$ With a push to reduce metallization cost in c-Si technology roadmap, alternative contact scheme based on $\mathrm{Ni}-\mathrm{Cu}$ stack is being considered. ${ }^{3,4}$ The nickel seed layer prevents diffusion of copper in silicon and formation of nickel silicide at the interface reduces contact resistance with improvement in adhesion of metal stack.

Electroless nickel plating is a well-established process ${ }^{5}$ and ideally suited to deposit the seed layer on semi-conducting surface as electroplating process requires a conducting substrate for deposition. Masking to prevent deposition on unpatterned regions would be provided by the anti-reflective coating of solar cell. One of the important aspects related to solar cell metallization is that nickel diffusion through the emitter and bulk material can lead to shunt formation and reduction in minority carrier life time..$^{6,7}$ To avoid these detrimental effects, annealing of nickel seed layer is typically done in temperature range of $300-500^{\circ} \mathrm{C}$ for short

\footnotetext{
*Author for correspondence (mehul.c.raval@iitb.ac.in)
}

durations. ${ }^{3,4,8-12}$ However, a clear relation does not exist between annealing conditions and nickel silicide formation with associated contact resistivity of the interface, though studies have been performed for higher temperature ranges. ${ }^{13,14}$

In the present work, a thin electroless nickel seed layer is deposited with and without Pd activation to study silicide formation and contact resistivity at the interface for annealing durations of $30-60 \mathrm{~s}$ in temperature range of $400-420^{\circ} \mathrm{C}$. Phase identification studies for the seed layer and silicides is performed using X-ray diffraction (XRD) technique. The analysis gives a clearer understanding of influence of seed layer deposition process and the annealing conditions from solar cell metallization point of view.

\section{Experimental}

c-Si p-type wafer (100) of resistivity $1-3 \Omega \mathrm{cm}$ and thickness of $220 \mu \mathrm{m}$ which have undergone standard solar cell fabrication of texturing, diffusion (40-60 $\Omega / \square$ ) and ARC deposition of 75-80 $\mathrm{nm}$ were used for transfer length method (TLM) sample preparation and observing silicide morphology evolution. Patterning of the ARC was done by coating self-adhesive polymer which is then patterned by $\mathrm{CO}_{2}$ laser operating at $3-5 \mathrm{~W}$ with a wavelength of $10,000 \mathrm{~nm}^{15}$

An optimized electroless bath with $\mathrm{NiCl}_{2}$ and $\mathrm{NaH}_{2} \mathrm{PO}_{2}$ concentrations of 30 and $20 \mathrm{~g} \mathrm{l}^{-1}$ are used for nickel 
deposition. ${ }^{15}$ Bath temperature was varied in range of $70-90^{\circ} \mathrm{C}$ for neutral $\mathrm{pH}$ and acidic baths, while a temperature of $90-95^{\circ} \mathrm{C}$ was used an alkaline bath. Pd-based activation ${ }^{16}$ is used for plating from acidic and neutral baths. Plating duration is in range of 60-120 s for seed layer thickness of around $140 \mathrm{~nm}$. Subsequently, the samples are annealed at $400-420^{\circ} \mathrm{C}$ in a tube-furnace with $\mathrm{N}_{2}$ ambient. Unreacted nickel is etched in $\mathrm{H}_{2} \mathrm{SO}_{4}: \mathrm{H}_{2} \mathrm{O}_{2}$ (1:1) solution for observing the surface morphology after silicidation.

Nickel seed layer growth and silicide morphology are observed using scanning electron microscopy (SEM), while Grazing Incidence XRD (GIXRD) measurements are performed with grazing angle of $0.5^{\circ}$ and scan rate of $0.01^{\circ} \mathrm{s}^{-1}$ in $2 \theta$ range of $30-70^{\circ}$ to obtain detailed phase formation information for various annealing conditions. TLM approach is used for contact resistivity $\left(\rho_{\mathrm{c}}\right)$ measurements for various annealing conditions. ${ }^{15}$
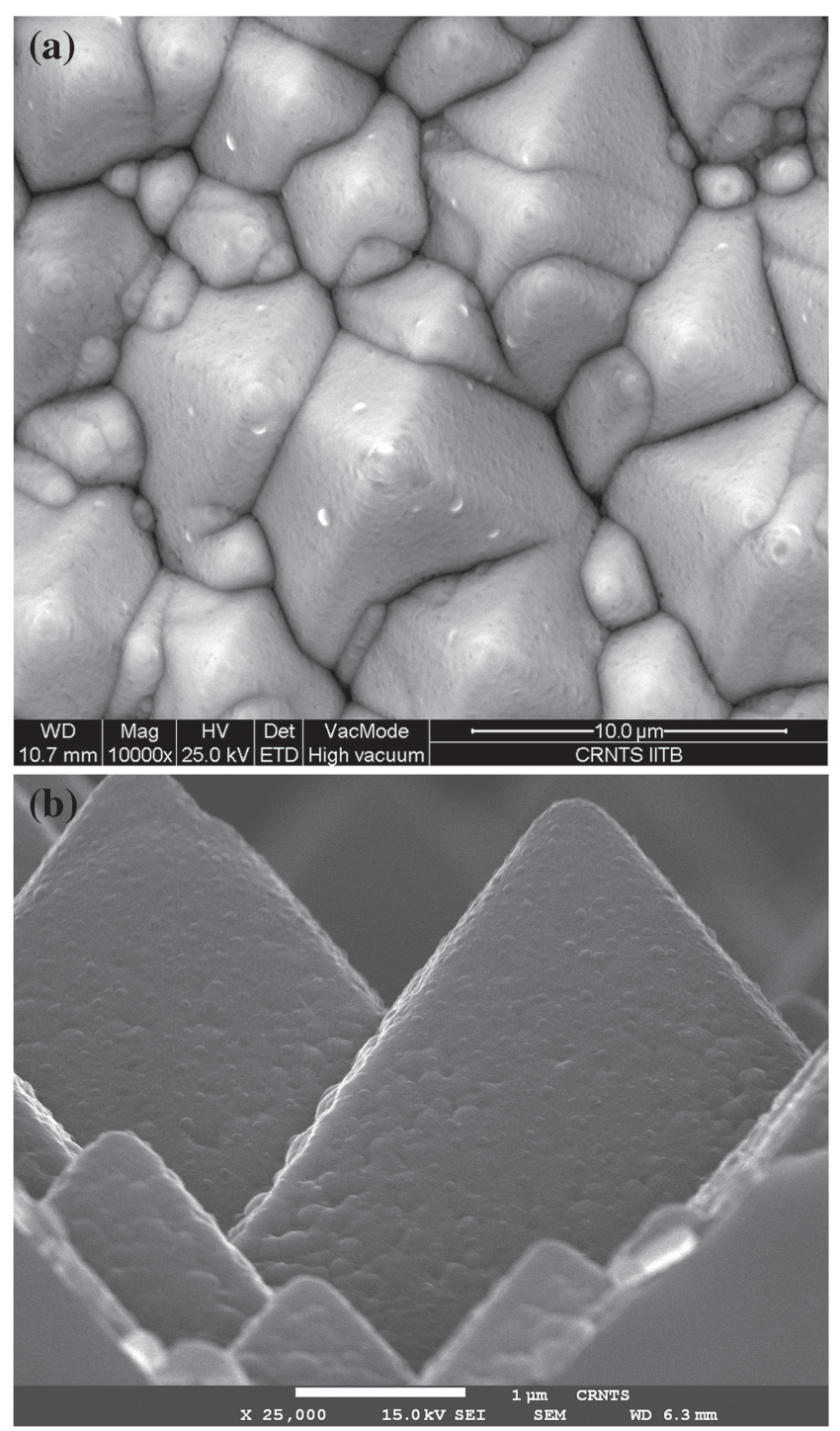

Figure 1. Electroless nickel deposition from (a) neutral $\mathrm{pH}$ bath for $3 \mathrm{~min}$ and (b) alkaline bath for $1 \mathrm{~min}$.

\section{Results and discussion}

\subsection{Nickel seed layer growth and contact resistivity studies}

Homogeneous deposition is obtained for neutral and alkaline baths with plating intervals up to $3 \mathrm{~min}$ as shown in figure 1. Seed layer thickness is approximately $140 \mathrm{~nm}$ for deposition of $1 \mathrm{~min}$ in both cases with low phosphorus content of 5\% (by weight) as determined by energy dispersive X-ray spectroscopy. Acidic bath was found unsuitable due to non-homogeneous particle growth which may result in presence of voids in the seed layer. As-plated seed layers have $\rho_{\mathrm{c}}$ values of greater than $18 \mathrm{~m} \Omega \mathrm{cm}^{2}$ which decreases to average value of 7.7 and $5.9 \mathrm{~m} \Omega \mathrm{cm}^{2}$ for seed layer deposited from neutral and alkaline baths, respectively. Contact resistivity trend with varying annealing conditions is indicated in figure 2. Reduced contact resistivity is obtained

(a)

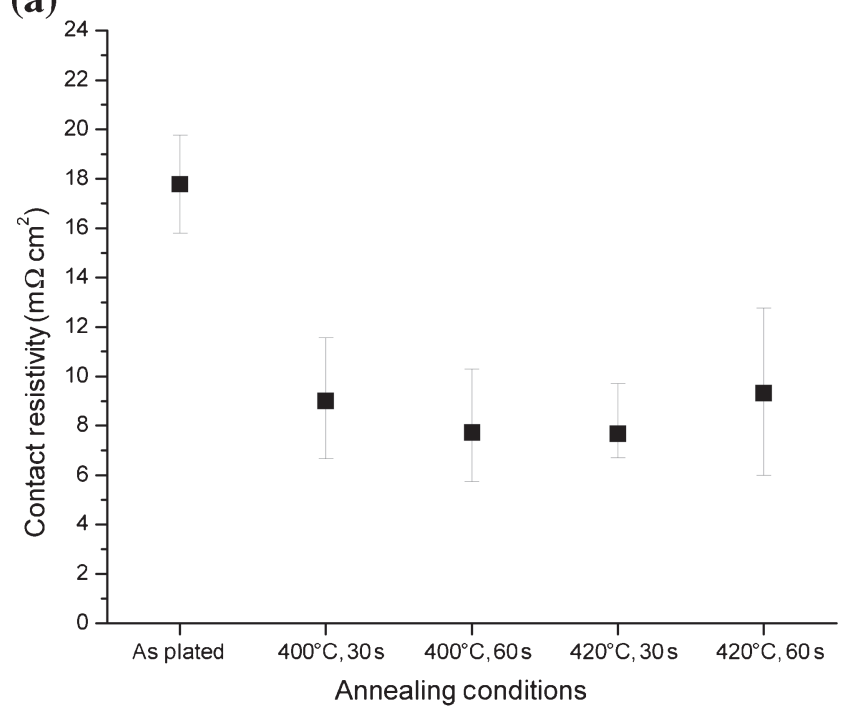

(b)

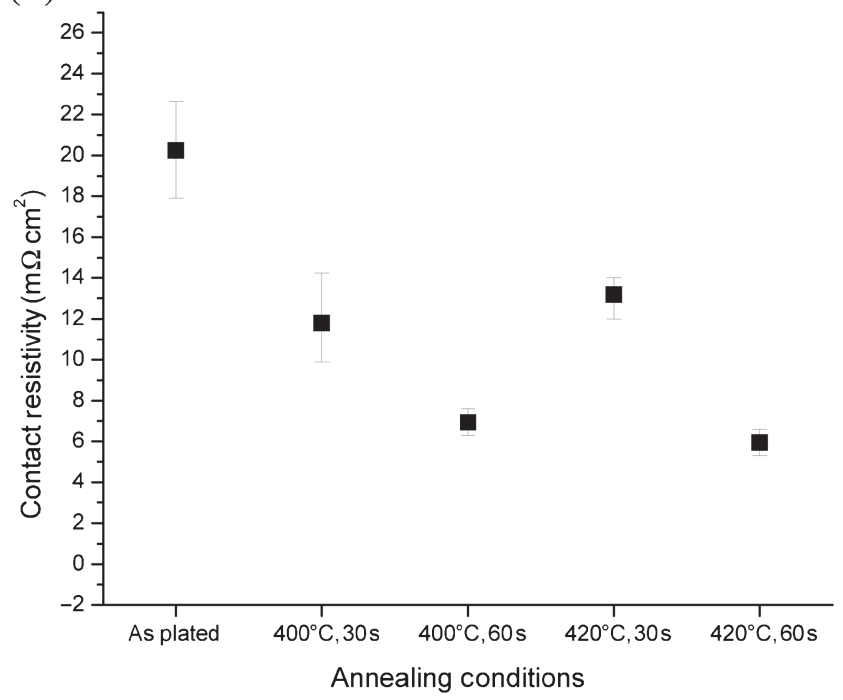

Figure 2. Contact resistivity variation for (a) activated samples and (b) non-activated samples. 

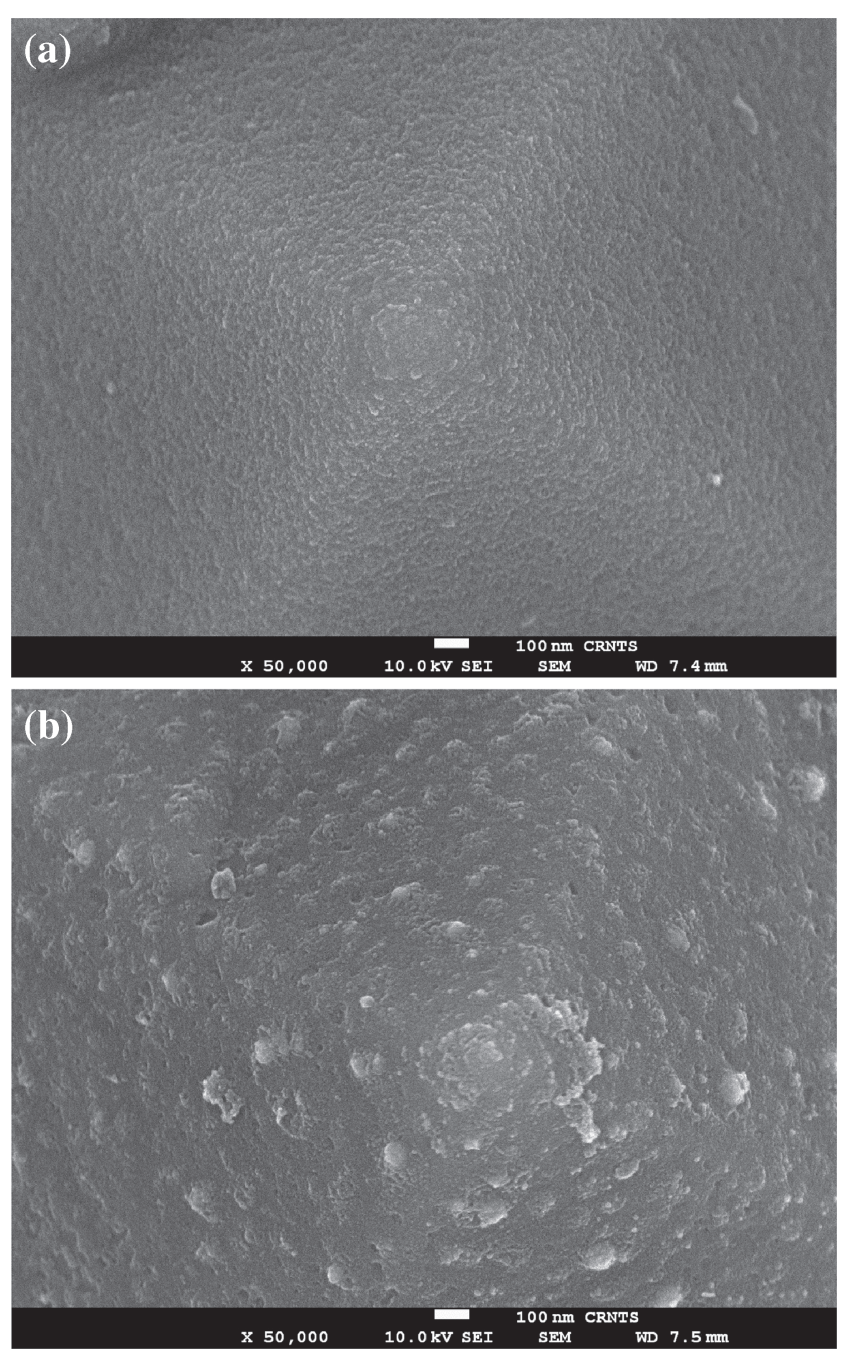

Figure 3. Silicide morphology for seed layer deposited from neutral $\mathrm{pH}$ bath (a) annealed at $400^{\circ} \mathrm{C}$ for $1 \mathrm{~min}$ and (b) annealed at $420^{\circ} \mathrm{C}$ for $1 \mathrm{~min}$.

for non-activated samples with increased annealing duration, while significant difference is not observed in case of activated samples.

\subsection{Silicide morphology and phase formation}

Silicide morphology for seed layer deposited from neutral bath is shown in figure 3. Silicide formation is uniform over the pyramid for annealing at $400^{\circ} \mathrm{C}$, while hump-like formations are evident for higher annealing temperature. For seed layer deposition from alkaline bath, silicide formation is relatively even for a short annealing duration at $400^{\circ} \mathrm{C}$ with prominent roughening at many sites for increased duration as indicated in figure 4 . The observations indicate that temperature in range of $350-400^{\circ} \mathrm{C}$ with short duration should be suitable for seed layer annealing to reduce the probability of nickel diffusion through the emitter.

Nickel deposition from an alkaline bath is initiated via galvanic displacement with silicon substrate, where the nickel
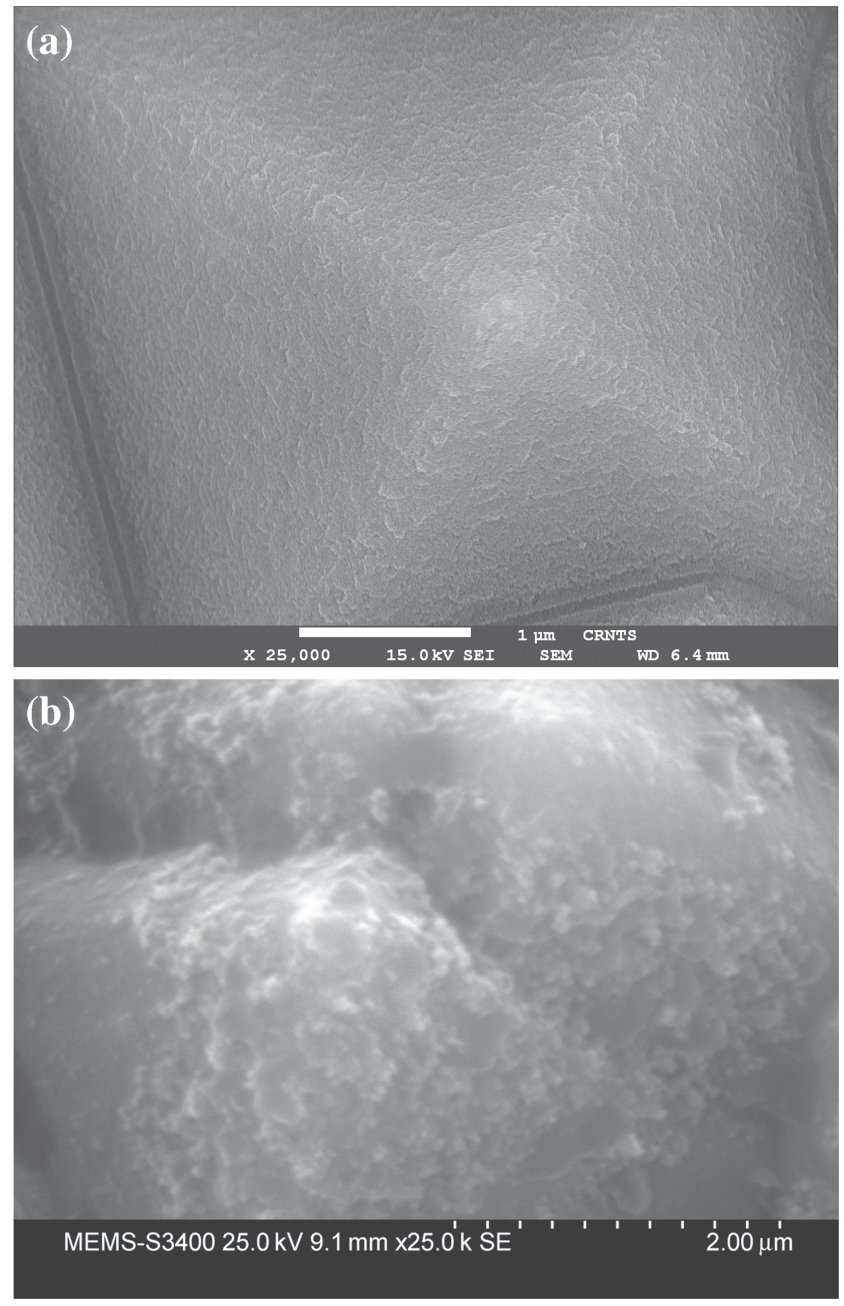

Figure 4. Silicide morphology for seed layer deposited from alkaline bath (a) annealed at $400^{\circ} \mathrm{C}$ for $30 \mathrm{~s}$ and (b) annealed at $400^{\circ} \mathrm{C}$ for $1 \mathrm{~min}$.

cations receive electrons through electrochemical oxidation of silicon. ${ }^{17}$ Subsequently, nickel deposition proceeds autocatalytically through the reducing agent. The galvanic displacement process leads to formation of a non-homogeneous $\mathrm{SiO}_{2}$ layer at the $\mathrm{Ni}-\mathrm{Si}$ interface ${ }^{17}$ and hence non-uniform migration of nickel atoms during silicide formation. Similar observations for nickel silicide formation have also been made by Fisher. ${ }^{18}$ As compared to deposition without activation, Pd-based activation leads to regular nucleation of nickel particles and hence relatively uniform silicide formation. Despite the advantage of uniform silicide formation, Pdbased activation can lead to significant background plating which will degrade the solar cell performance ${ }^{19}$ and hence would require further optimization by reducing bath temperature or altering the activation process. ${ }^{18}$

Crystallization of the nickel seed layer occurs for increased annealing temperature, while prominent growth of nickel phosphides is observed from the XRD measurements shown in figure 5. It is known that annealing electroless nickel above $400^{\circ} \mathrm{C}$ leads to formation of nickel phosphide 


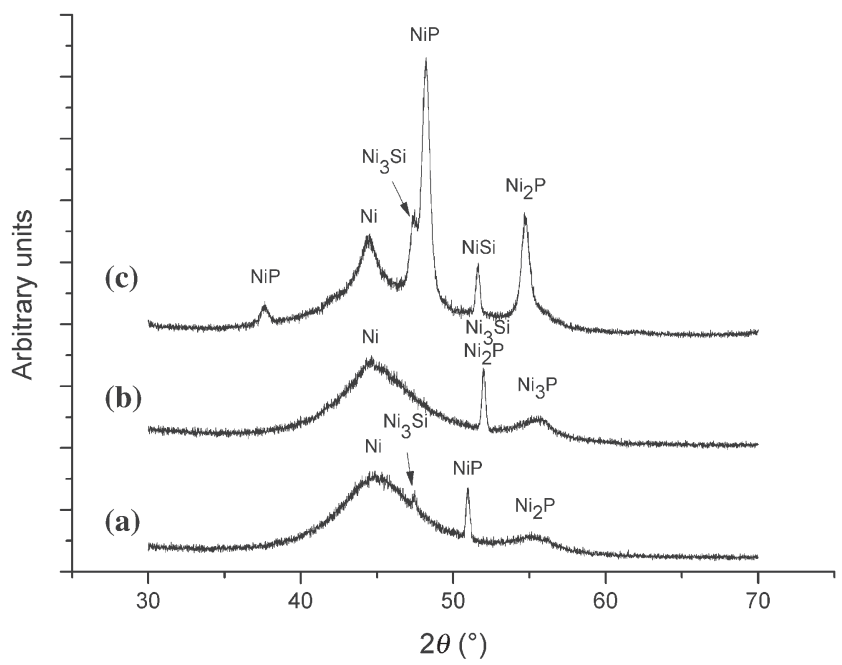

Figure 5. GIXRD data for $140 \mathrm{~nm}$ nickel seed layer annealed for 1 min at (a) $350^{\circ} \mathrm{C}$, (b) $400^{\circ} \mathrm{C}$ and (c) $450^{\circ} \mathrm{C}$.

$\mathrm{Ni}_{3} \mathrm{P}$ with one or more intermediate phosphides, ${ }^{20-22}$ while the equilibrium state of nickel with $0-15 \%$ (weight) $\mathrm{P}$ is $\mathrm{Ni}+\mathrm{Ni}_{3} \mathrm{P}^{22} \mathrm{Ni}_{2} \mathrm{P}$ might have also been present in the as-deposited films as has been inferred in Randin and Hintermann, ${ }^{23}$ but might not be detected due to overlapping peak with Ni-P. The presence of nickel phosphides along with additional impurities like $\mathrm{SiO}_{2}$ will significantly affect the silicidation process. Formation of metal-rich $\mathrm{Ni}_{3} \mathrm{Si}$ phase is attributed to isolated $\mathrm{Ni}_{2} \mathrm{Si}-\mathrm{Si}$ interfaces with limited supply of silicon. ${ }^{24}$ The desirable NiSi phase is only observed at a higher annealing temperature of $450^{\circ} \mathrm{C}$. Since $\mathrm{Ni}_{3} \mathrm{Si}$ phase has much higher resistivity compared to $\mathrm{NiSi}$ or $\mathrm{Ni}_{2} \mathrm{Si}$ phases ${ }^{25}$ it will limit the decrease in contact resistivity at the $\mathrm{Ni}-\mathrm{Si}$ interface.

\section{Conclusions}

A uniform and low phosphorus content thin nickel seed layer is deposited from neutral and alkaline electroless baths for solar cell metallization. The contact resistivity of as-plated seed layer is greater than $18 \mathrm{~m} \Omega \mathrm{cm}^{2}$ which reduces to $7 \mathrm{~m} \Omega \mathrm{cm}^{2}$ for seed layer deposited from alkaline bath and annealed at $400^{\circ} \mathrm{C}$. Pd-based activation leads to uniform silicide formation, while deposition from alkaline bath leads to non-homogeneous silicide formation even for short annealing duration at $400^{\circ} \mathrm{C}$. A temperature range of $350-400^{\circ} \mathrm{C}$ with short duration is recommended for annealing to avoid nickel diffusion through the emitter. The presence of nickel phosphides and $\mathrm{SiO}_{2}$ in the seed layer and at $\mathrm{Ni}-\mathrm{Si}$ interface play a critical role in silicide formation and leads to formation of metal-rich silicide phase $\mathrm{Ni}_{3} \mathrm{Si}$ due to isolated $\mathrm{Ni}_{2} \mathrm{Si}-\mathrm{Si}$ regions with limited supply of silicon. Since $\mathrm{Ni}_{3} \mathrm{Si}$ has higher resistivity compared with $\mathrm{NiSi}$ and $\mathrm{Ni}_{2} \mathrm{Si}$ phases, it will limit the reduction in contact resistivity for $\mathrm{Ni}-\mathrm{Cu}$-based metallization.

\section{Acknowledgements}

We would like to thank the staff at Materials Characterization Lab, MEMS and SAIF at IITB, for SEM measurements. We would also like to acknowledge the time and efforts of Pradeep M.L. and Prahlada at CeNSE, IISc for GIXRD measurements. This work was supported by National Centre for Photovoltaic Research and Education (NCPRE), funded by the Ministry of New and Renewable Energy (MNRE), Government of India.

\section{References}

1. Green M 2011 Prog. Photovolt: Res. Appl. 19911

2. Kamp M, Bartsch J, Nold S, Retzlaff M, Hörteis M and Glunz S W 2011 Energy Procedia 8558

3. Kim D S, Lee E J, Kim J and Lee S H 2005 J. Korean Phys. Soc. 461208

4. Bartsch J, Mondon A, Godejohann B J, Hörteis M and Glunz S W 2010 Proceedings of 25th European photovoltaic solar energy conference and exhibition/5th world conference on photovoltaic energy conversion p. 1978

5. Mallory G O and Hajdu J B 1990 Electroless plating: fundamentals and applications (New York: Noyes Publications/ William Andrew Publishing)

6. Alemàn M, Bay N, Barucha D, Knorz A, Biro D, Preu R and Glunz S W 2009 Proceedings of 24th PV solar energy conference and exhibition p. 1414

7. Istratov A A and Weber E R 1998 Appl. Phys. A 66123

8. Nguyen A, Rane-Fondacaro M V, Efstathiadis H, Haldar P, Michealson L, Wang C, Munoz K, Tyson T and Gallegos A 2010 Proceedings of 25th PV solar energy conference and exhibition p. 2672

9. Lee E J, Kim D S and Lee S H 2002 Sol. Energy Mater. C 7465

10. Chaudhari V A and Solanki C S 2010 Sol. Energy Mater. C 94 2094

11. Bandopadhyay S, Gangopadhyay U, Mukhopadhyay K, Saha H and Chaterjee A P 1992 Bull. Mater. Sci. 15473

12. Braun S, Emre E, Raabe B and Hahn G 2010 Proceedings of 25th European photovoltaic solar energy conference and exhibition/5th world conference on photovoltaic energy conversion p. 1892

13. Boulord C, Kaminski A, Canut B, Cardinal S and Lemiti M 2010 J. Electrochem. Soc. 157 H742

14. Eun K L, Dong C L, Kyu H L and Jae-Hong L 2012 Electron. Mater. Lett. 8391

15. Chaudhari V A 2010 Design and development of low concentrator c-silicon solar cells Ph.D. Thesis (Department of Energy Science and Engineering, Indian Institute of TechnologyBombay)

16. Vitanov P, Tyutyundzhiev N, Stefchev P and Karamfilov B 1996 Sol. Energy Mater. C 44471

17. Takano N, Hosoda N, Yamada T and Osaka T 1999 J. Electrochem. Soc. 1461407

18. Fisher K 2004 The pitfalls of pit contacts: electroless metallization for c-Si solar cells B.E. Thesis (Australia: School of Photovoltaics and Renewable Energy Engineering, UNSW) 
19. Raval M C, Joshi A and Solanki C S 2012 Proceedings of 27th $P V$ solar energy conference and exhibition $\mathrm{p} .1234$

20. Keong K G, Sha W and Malinov S 2002 J. Mater. Sci. 374445

21. Lambert M R and Duquette D J 1989 Thin Solid Films 177207

22. Ray T 2003 Evaluation of electroless nickel-phosphorus (EN) coatings Ph.D. Thesis (Department of Mechanical Engineering, University of Saskatchewan)
23. Randin J P and Hintermann H E 1970 J. Electrochem. Soc. 117 160

24. Canali C, Majni G, Ottaviani G and Celotti G 1979 J. Appl. Phys. 50255

25. Lavoie C, Detavernier C and Besser P 2009 Silicide Technology for Integrated Circuits Chen L J (ed) (London: The Institution of Engineering and Technology) Chapter 5, p. 102 